\title{
Immune correlates of XMRV infection
}

\author{
Vincent Lombardi ${ }^{1}$, Deborah Goetz ${ }^{2}$, Max Pfost ${ }^{1}$, Cassandra Puccinelli ${ }^{1}$, Judy Mikovits ${ }^{\text {* }}$ \\ From 15th International Conference on Human Retroviruses: HTLV and Related Viruses \\ Leuven and Gembloux, Belgium. 5-8 June 2011
}

\section{Background}

CFS patients often display antiviral enzyme RNase L dysfunction underscoring the importance of the innate immune response in CFS. We reported the XMRV detection in the peripheral blood of $67 \%$ of a cohort of CFS patients and $3.4 \%$ of controls [1]. XMRV infection may play a role in CFS pathogenesis through the dysregulation of the immune response.

\section{Methods}

This hypothesis was addressed by multiplex profiling of plasma cytokines and chemokines on a LuminexTM platform and phenotypic analysis of leukocyte subsets by multi-parameter flow cytometry in XMRV infected CFS patients versus uninfected controls. XMRV-infected subject and control samples were assayed blindly. Analysis was performed using the Gene Expression Pattern Analysis Suite and Random Forest tree classification algorithms. For immune profiling, $63 \mathrm{XMRV}$ infected CFS patient samples were analyzed within 6 hours using an LSRII flow cytometer with BD FACSDiva software. Six normal donors and reference values based on a healthy population were used as normal baselines.

\section{Results}

16 of the 26 cytokines/chemokines measured were significantly differentially expressed; eleven up-regulated and five down-regulated including: IL-8, IL-6, MIP1 $\alpha$ lpha, MCP-1, IFNalpha and TNFalpha. XMRV-infected CFS patients showed reduced percentages of CD56+ NK and CD19+ B cells. The NK phenotype in XMRV-infected CFS patients was altered, with $80 \%$ of the patients having a significantly reduced CD56+DIM population. The B cells present in the peripheral blood were CD20+, CD23 + mature B cells.

\section{Conclusion}

XMRV infection results in dysregulation of the immune response, either directly by infection of specific leukocyte subsets or indirectly through cytokine modulation.

\section{Author details}

${ }^{1}$ Whittemore Peterson Institute, Reno, NV, 89557, USA. Environmental

Sciences,University of Nevada, Reno, NV, 89557, USA.

Published: 6 June 2011

\section{Reference}

1. Lombardi V, Ruscetti F, Das Gupta J, Pfost M, Hagen K, Peterson D, Ruscetti S, Bagni R, Petrow-Sadowski C, Gold B, Dean M, Silverman R, Mikovits J: Detection of an Infectious Retrovirus, XMRV, in Blood Cells of Patients with Chronic Fatigue Syndrome. Science 2009, 326:585-589.

\section{doi:10.1186/1742-4690-8-S1-A221}

Cite this article as: Lombardi et al:: Immune correlates of XMRV infection. Retrovirology 2011 8(Suppl 1):A221.

* Correspondence: judym@wpinsitute.org

${ }^{1}$ Whittemore Peterson Institute, Reno, NV, 89557, USA

Full list of author information is available at the end of the article

Submit your next manuscript to BioMed Central and take full advantage of:

- Convenient online submission

- Thorough peer review

- No space constraints or color figure charges

- Immediate publication on acceptance

- Inclusion in PubMed, CAS, Scopus and Google Scholar

- Research which is freely available for redistribution
C Biomed Central

\section{Biomed Central}

